\title{
PERAN DEWAN PENGAWAS SYARIAH (DPS) DAN DEWAN SYARIAH NASIONAL MAJELIS ULAMA INDONESIA (DSN- MUI) DALAM PENGEMBANGAN INDUSTRI WISATA HALAL INDONESIA
}

Noor Kholifah Hidayati ${ }^{*}$

Fakultas Hukum, Universitas Diponegoro, Semarang, Indonesia Ro'fah Setyowati

Fakultas Hukum, Universitas Diponegoro, Semarang, Indonesia Ninik Zakiyah

Universitas Islam Negeri Walisongo Semarang, Semarang, Indonesia

\section{Abstract}

The synergy of DPS and DSN-MUI as a determinant of the implementation of Islamic principles in the financial sector greatly influences the development of sharia economic law in Indonesia. Sharia Economic Law such as the fatwa product from the DSN-MUI should be able to become a legal umbrella for the financial sector and the real sharia sector in Indonesia, but in fact the influence given by the fatwa and its regulators, namely the DSN-MUI and DPS in the real and financial sectors is still deemed not balanced. This paper uses a normative-juridical method with a historical approach, a conceptual approach and a law approach, and uses a qualitative juridical analysis method. The results show that, first, the role of DSN-MUI as an external supervisor and DPS as an internal supervisor has a major influence on sharia compliance in the financial sector. Second, the dominance of the touch of DSN-MUI and DPS only exists in

Paper type: Research paper

*Corresponding author: kholifahhidayati@students.undip.ac.id

Received: March 05, 2021; Accepted: November 13, 2021; Available online: December, 06, 2021

Cite this document:

Hidayati, N. K., Setyowati, R., \& Zakiyah, N. (2021). Peran Dewan Pengawas Syariah (DPS) dan Dewan Syariah Nasional Majelis Ulama Indonesia (DSNMUI) dalam Pengembangan Industri Wisata Halal Indonesia. Jurnal Masharif AlSyariah: Jurnal Ekonomi dan Perbankan Syariah, 6(3), 709-732. doi:http://dx.doi.org/10.30651/jms.v6i3.7585

Copyright (C) 2021, Jurnal Masharif Al-Syariah: Jurnal Ekonomi dan Perbankan Syariah

http://journal.um-surabaya.ac.id/index.php/Mas/index

This article is licensed under a Creative Commons Attribution-NonCommercial 4.0 International License. 
the Islamic finance sector, while the real sector has not been closely monitored by DPS. Third, the real sector of the halal tourism industry that is labeled with sharia still does not meet the sharia compliance principles specified in the DSN-MUI fatwa. This study is important considering the fact that the role of the DSN-MUI in issuing fatwas on new sharia products and supervision of DPS in the real sector must be carried out immediately because the real sector in the sharia industry has developed a lot and can reduce the level of trust of the sharia economy community if it is not accompanied by proper guidelines and supervision. optimal.

Keywords: DSN-MUI; DPS; halal tourism; financial sector; real sector

\begin{abstract}
Abstrak
Sinergitas DPS dan DSN-MUI sebagai penentu implementasi prinsip Islam pada sektor keuangan sangat mempengaruhi perkembangan hukum ekonomi syariah di Indonesia. Hukum Ekonomi Syariah seperti produk fatwa dari DSN-MUI mestinya dapat menjadi payung hukum bagi sektor keuangan dan sektor riil syariah di Indonesia, namun faktanya pengaruh yang diberikan dari fatwa tersebut beserta regulatornya yaitu DSN-MUI dan DPS pada sektor riil dan keuangan masih dirasa belum seimbang. Tulisan ini menggunakan metode yuridis-normatif dengan pendekatan historis, pendekatan konseptual dan pendekatan Undang-Undang, serta menggunakan metode analisis yuridis kualitatif. Hasil penelitian menunjukkan bahwa, pertama, peran DSN-MUI sebagai pengawas eksternal dan DPS sebagai pengawas internal berpengaruh besar pada kepatuhan prinsip syariah di sektor keuangan. Kedua, dominasi sentuhan DSN-MUI dan DPS hanya ada di sektor keuangan syariah, sedangkan sektor riil belum diawasi secara ketat oleh DPS. Ketiga, sektor rill industri wisata halal yang berlabel syariah masih kurang memenuhi prinsip kepatuhan syariah yang ditentukan dalam fatwa DSN-MUI. Kajian ini menjadi penting melihat fakta bahwa peran DSN-MUI untuk mengeluarkan fatwa produk syariah baru dan pengawasan DPS pada sektor riil harus segera dilakukan karena sektor riil di indusri syariah telah banyak berkembang dan dapat menurunkan tingkat kepercayaan masyarakat ekonomi syariah jika tidak diiringi pedoman dan pengawasan yang optimal.
\end{abstract}

Kata kunci: DSN-MUI; DPS; wisata halal; sektor keuangan; sektor riil

\title{
PENDAHULUAN
}

Perkembangan lembaga keuangan ekonomi syariah terus tumbuh, mulai dari beberapa tambahan unit syariah dari bank-bank konvensional, hingga lembaga keuangan lainnya dari mikro hingga makro. Basis 
ekonomi syariah pada lembaga keuangan tersebut tentunya didukung dengan menggunakan prinsip syariah dalam operasionalnya yaitu berdasarkan al-Quran dan Sunnah. Islam mengatur hubungan antar manusia dengan manusia lainnya meliputi harta kekayaan, hak-hak kebendaan, dan penyelesaian sengketa, atau disebut fiqih muamalah.

Fiqih muamalah bertransformasi ke dalam perundang-undangan yang mengatur hukum ekonomi syariah di Indonesia. Sehingga urgensinya semakin menguat dalam mengimplementasikan prinsip-prinsip syariah pada perekonomian di Indonesia yang berlandaskan al-Quran dan Sunnah, agar dalam praktiknya perekonomian Indonesia memang benarbenar menjalankan syariat agama secara benar, baik dalam transaksinya maupun pelayananya, bukan hanya labeling semata (Ulumi, 2020). Allah berfirman tentang kewajiban untuk taat dalam mengikuti syariah atau aturan yang telah ditetapkan oleh Allah:

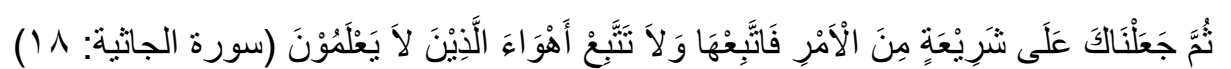

"Kemudian Kami jadikan engkau (Muhammad) mengikuti syariat (peraturan) dari agama itu, maka ikutilah (syari'at itu) dan janganlah engkau ikuti keinginan orang-orang yang tidak mengetahui" (Q.S. Al-Jaatsiyah:18)

Di Indonesia, penegakan ekonomi syariah tidak terlepas dari regulasi Pemerintah, supaya instrumen ekonomi syariah dapat dijadikan sebagai bagian kebijakan ekonomi nasional. Internalisasi nilai-nilai ekonomi syariah perlu ditegakkan dalam hal inwal perekonomian Indonesia, sehingga dalam menjalankan regulasi tersebut ada ekspansi kelembagaan atau institusi dalam menjalankannya. Undang-Undang Perbankan Syariah sebagai suatu simbol regulasi yang berlandaskan ekonomi syariah, dan keberadaan institusi lain yang berperan penting dalam pertumbuhan ekonomi syariah seperti KNEKS (Komite Nasional Ekonomi dan Keuangan Syariah) (Iswanto, 2016).

Di sisi lain, implementasi sistem ekonomi syariah di Indonesia, tidak hanya pada sektor keuangan, namun juga sudah meluas ke sektor riil. Namun demikian, perhatian yang diberikan oleh stake holder, terhadap dua sektor tersebut, belum seimbang. Sektor riil seperti sektor industri dan 
perdagangan yang hampir luput dalam kacamata ekonomi syariah. Padahal, sektor riil merupakan praktik nyata dalam menghasilkan produk halal. Jika sistem keuangan syariah hanya mengedepankan tujuan keuntungan finansial, akibatnya pelaku ekonomi hanya fokus pada ekonomi yang sifatnya spekulatif (non-riil), misalnya jual-beli surat berharga (saham dan obligasi) atau kegiatan transaksi dalam perbankan. Dampaknya porsi untuk kegiatan produksi barang dan jasa yang sesuai syariah semakin berkurang, kemudian mengakibatkan pertumbuhan sektor riil (investasi produktif) melambat dan berakhir pada ketidakseimbangan laju ekonomi syariah (Risal, 2019).

Skema yang mestinya terjadi yaitu sektor keuangan dan sektor riil dapat saling bersinergi untuk menghasilkan produk halal dan jasa yang sesuai prinsip syariah, misalnya pada lembaga keuangan syariah dan indutri wisata halal. Dalam Fatwa Dewan Syariah Nasional-Majelis Ulama Indonesia No. 108/DSN-MUI/X/2016 Tentang Pedoman Penyelenggaraan Pariwisata Berdasarkan Prinsip Syariah ditentukan bahwa biro perjalanan wisata syariah harus menggunakan jasa lembaga keuangan syariah dalam melakukan pelayanan jasa wisata, baik bank, asuransi, lembaga pembiayaan, penjaminan, maupun dana pensiun, serta pengelolaan dana dan investasinya wajib sesuai dengan prinsip syariah (Mahardika, 2020). Jelas bahwa lembaga keuangan dan perbankan syariah memegang salah satu faktor penentu keabsahan biro perjalanan wisata halal dan wajib berperan menyediakan layanan transaksi yang benar-benar sesuai dengan prinsip Islam (Sidharta, 2018). Berlakunya fatwa tersebut membuat bank syari'ah dan industri wisata halal berkaitan erat serta tidak dapat dipisahkan satu sama lain. Permasalahannya, banyak ditemukan ketidakpatuhan pemenuhan prinsip syariah yang dalam hal ini yaitu industri wisata halal yang masih menggunakan layanan transaksi nonsyariah (konvensional) pada produk jasanya.

Fatwa-fatwa yang mengatur aktivitas ekonomi dan keuangan syariah sebagaimana disebutkan sebelumnya, dikeluarkan oleh Dewan Syariah Nasional-Majelis Ulama Indonesia (selanjutnya disebut DSN-MUI). DSN- 
MUI dibentuk pada tanggal 10 Februari 1999 dengan adanya SK No. Kep754/MUI/II/1999 Tentang Pembentukan Dewan Syariah Nasional Majelis Ulama Indonesia. Dibentuknya DSN-MUI karena adanya perkembangan pada Lembaga Keuangan Syariah di Indonesia, sehingga Majelis Ulama Indonesia (MUI) memutuskan perlunya satu Lembaga untuk mendukung dan mengembangkan keberadaan Lembaga Keuangan Syariah yang berwenang mengeluarkan fatwa, sehingga dapat memberi kemaslahatan dalam perkembangan aktivitas ekonomi syariah di Indonesia. Maka fatwafatwa yang dikeluarkan DSN-MUI bertujuan untuk melindungi operasional institusi keuangan syariah agar berjalan sesuai prinsip islam (Syaifullah, 2019).

Konsekwensi logis dari pelaksanaan regulasi untuk penerapan hukum ekonomi syariah adalah diperlukan institusi yang dibentuk untuk mengawal implementasi fatwa-fatwa dari DSN-MUI. Maka dibentuklah Dewan Pengawas Syariah (selanjutnya disebut DPS) untuk memastikan bahwa fatwa DSN-MUI benar-benar diterapkan dalam lapangan perekonomian syariah di Indonesia. Kehadiran DPS sebagai akibat hukum dari keputusan Dewan Syariah Nasional Majelis Ulama Indonesia (DSNMUI) No.Kep-98/MUI/III/2001 Tentang Susunan Pengurus DSN-MUI Bagian Peran DPS, sehingga DPS memiliki fungsi secara periodik mengawasi lembaga keuangan syariah (Munthe, dkk, 2019).

Berkaitan dengan pengawasan lembaga keuangan syariah oleh anggota DPS, maka keanggotaan dari DPS diharuskan mumpuni dalam segi keilmuan secara komprehensif dan integral dalam fiqih muamalah maupun ekonomi Islam, dengan demikian pengawasan yang terus berjalan didukung dengan kualifikasi akademik dari anggota DPS yang profesional, sehingga bekerjanya lembaga keuangan ekonomi syariah dapat berjalan dengan baik serta semakin meningkat pula syariah compliance-nya (Mujib, 2016). Namun, peran DPS sebagai kepanjangan tangan DSN-MUI dalam mengimplementasikan prinsip syariah sampai saat ini hanya mendominasi sektor keuangan. Dominasi pengawasan yang terjadi dalam sektor keuangan berdampak pada luputnya 
pengawasan sektor riil dalam industri pengadaan jasa dan produk halal. Salah satu contoh kurangnya pengawasan DPS pada sektor riil telah terjadi di industri wisata halal. Beberapa penelitian yang dilakukan antara lain oleh Abdul Mujib dengan judul "Analisis terhadap Konsep Syariah pada Industri Perhotelan di Indonesia" [8], Dewi Masdaleny dengan judul "Praktek Pengembangan Pariwisata Syariah dalam Perspektif Fatwa DSNMUI No. 108/DSN-MUI/X/2016"[9] dan Emi Rahmawati dengan judul "Analisis Fatwa DSN-MUI Nomor: 108/DSN-MUI/X/2016 Tentang Pedoman Penyelenggaraan pariwisata Berdasarkan Prinsip Syariah di Hotel Multazam Syariah", membuktikan bahwa kurangnya pengawasan DPS berdampak pada kurangnya kepatuhan syariah di industri tersebut.

Beberapa penelitian yang cukup relevan dengan tulisan ini telah ditulis sebelumnya oleh Eja Armaz Hardi, dengan judul "Fatwa DSN MUI dan Perkembangan Produk Perbankan Syariah di Indonesia" (Hardi, 2019), fokus pada pembahasan posisi fatwa DSN MUI dalam perkembangan produk dan jasa bank syariah sebagai tonggak kepatuhan syariah. Akan tetapi penelitian tersebut tidak membahas mengenai DPS dan kaitannya dengan sektor keuangan dan sektor riil. Penelitian A. Rio Makkulaku Wahyu dan Wirani Aisiyah dengan judul "Dewan Pengawasan Syariah Pada Bank Syariah (Tinjauan Undang-Undang Perbankan Syariah)" (Wahyu \& Anwar, 2020), fokus membahas DPS sebagai pengawas Bank Syariah berdasar pada UU Perbankan Syariah, serta tidak membahas mengenai DSN-MUI dan kaitannya dengan industry wisata halal di Indonesia. Penelitian oleh Taufiq Risal dengan judul "Peningkatan Peran Perbankan Syariah dengan Menggerakkan Sektor Riil dalam Pembangunan", fokus membahas metode untuk meningkatkan pembiayaan berbasis bagi hasil antara bank syariah dan sektor riil, tetapi tidak membahas tentang kaitan DSN-MUI dan DPS dalam perkembangan industri wisata halal di Indonesia. Sehingga urgensi penelitian ini semakin kuat sebab belum ditemukan penelitian yang fokus pada pembahasan peran DSN-MUI dan DPS dalam mengembangkan industri wisata halal di Indonesia. 
Penulis menentukan beberapa rumusan masalah pada tulisan ini antara lain; (1) Apa peran DPS dan DSN-MUI pada kepatuhan prinsip syariah di sektor keuangan? (2) Bagaimana dominasi pengawasan DPS dan DSN-MUI di sektor keuangan syariah? (3) Bagaimana tingkat kepatuhan sektor rill pada industri wisata halal di Indonesia? Sehingga penelitian ini ditulis untuk dapat menjawab rumusan masalah tersebut.

\section{KAJIAN PUSTAKA}

\section{Dewan Pengawas Syariah (DPS)}

Meninjau kembali sejarah islam pada zaman Rasulullah, lembaga pengawasan dikenal dengan Al-Hisbah. Secara etimologi, hisbah berasal dari kata hasaba yang artinya menghitung, mengkalkulasi, berpikir rinci, memberi opini, kemudian hisbah berarti pengujian, melakukan suatu perbuatan baik dengan penuh perhitungan. Sehingga secara harfiyah hisbah adalah suatu kewenangan dalam berbuat baik dengan penuh perhitungan (Baaqy, 1987).

Kemudian konsep pengawasan disini akan dijelaskan melalui pandangan Ibnu Taimiyyah. Beliau memang tidak menjelaskan secara rinci mengenai definisi Al-Hisbah, namun dapat dilihat dari kesimpulan tugas seseorang yang melakukan pengawasan atau muhtasib. Dalam bukunya pada bab tanggung jawab pengawas dijelaskan sebagai berikut:

$$
\begin{aligned}
& \text { و أما المحتسب فله الأمر بـالمعروف و النهي عن المنكر ممّا لبس من خصـائص الو لاة والقضـاة } \\
& \text { وأهل الديوان ونحوهم، وكثير من الأمور الدينية هو مشترك بين ولاة الأمور، فمن أدّى فيه الواجب وجبت }
\end{aligned}
$$

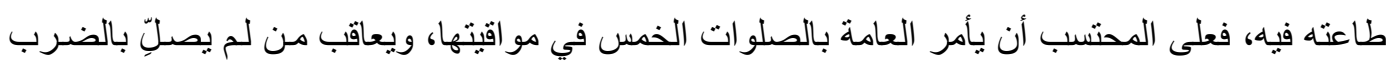

$$
\begin{aligned}
& \text { و الحبس، وأما القتل فإلى غيره [14]. }
\end{aligned}
$$

"Muhtasib diberi wewenang untuk memerintahkan (segala urusan) yang baik dan mencegah (segala urusan) yang munkar (yang urusannya) diluar kewenangan peradilan, pejabat administrasi lain dan yang sejenisnya. Termasuk hal-hal yang terkait dengan persoalan agama. Sehingga apa yang diwajibkan dalam agama, maka wajib pula ditaati (dan dilaksanakan). Muhtasib juga memerintahkan untuk sholat lima waktu tepat pada waktunya, dan memberi sanksi pada siapa yang belum menunaikan sholat dengan sanksi dera atau tahanan, tetapi mengenai pidana mati (kewenangannya) diserahkan kepada selain lembaganya." 
Penjelasan Ibnu Taimiyah di atas dapat disimpulkan bahwa AlHisbah merupakan dewan pengawas yang memiliki kewajiban amar ma'ruf wa nahyil munkar (memerintahkan kepada yang baik dan melarang kepada yang tidak baik) yang wewenangnya selain pada bidang peradilan, pejabat administrasi dan sejenisnya. Hal itu dapat diartikan bahwa wewenangnya ada dalam sektor ekonomi lembaga keuangan maupun non-keuangan yang mengatur segala aspek termasuk kedisiplinan dalam menjalankan syari'at (aturan agama).

Dalam konteks lembaga keuangan Islam di Indonesia, upaya pengawasan seperti Al-Hisbah dilakukan oleh Dewan Pengawas Syari'ah (DPS). Lembaga ini meskipun tidak mengawasi sedetail pengawasan Muhtasib soal kewajiban personal (sholat, puasa dan sebagainya), namun sudah merupakan kepanjangan tangan dari Dewan Syari'ah Nasional Majelis Ulama Indonesia (DSN-MUI) dan memenuhi standar sebagai dewan pengawas di lapangan.

\section{Dewan Syariah Nasional Majelis Ulama Indonesia (DSN-MUI)}

DSN dibentuk oleh Majelis Ulama Indonesia (MUI) dan telah diakui sejak adanya Surat Keputusan Direksi Bank Indonesia Nomor 32/34/KEP/DIR/1999 tentang Bank Umum Berdasarkan Prinsip Syari'ah. Dewan Syariah Nasional Majelis Ulama Indonesia (selanjutnya disebut DSN-MUI) dibentuk dalam rangka mewujudkan aspirasi umat Islam mengenai masalah perekonomian dan mendorong penerapan ajaran Islam dalam bidang perekonomian/keuangan yang dilaksanakan sesuai dengan tuntunan syariat Islam. Pembentukan DSN-MUI merupakan langkah efisiensi dan koordinasi para ulama dalam menanggapi isu-isu yang berhubungan dengan masalah ekonomi atau keuangan. Berbagai masalah yang memerlukan fatwa akan ditampung dan dibahas bersama agar diperoleh kesamaan pandangan dalam penanganannya oleh masingmasing Dewan Pengawas Syariah (DPS) yang ada di lembaga keuangan Syariah [15]. Dengan tujuan tersebut, DSN-MUI memiliki tugas-tugas penting antara lain: 
1) Menetapkan fatwa atas sistem, kegiatan, produk, dan jasa LKS, LBS, dan LPS lainnya;

2) Mengawasi penerapan fatwa melalui DPS di LKS, LBS, dan LPS lainnya;

3) Membuat Pedoman Implementasi Fatwa untuk lebih menjabarkan fatwa tertentu agar tidak menimbulkan multi penafsiran pada saat diimplementasikan di LKS, LBS, dan LPS lainnya;

4) Mengeluarkan Surat Edaran (Ta'limat) kepada LKS, LBS, dan LPS lainnya;

5) Memberikan rekomendasi calon anggota dan/atau mencabut rekomendasi anggota DPS pada LKS, LBS, dan LPS lainnya;

6) Memberikan Rekomendasi Calon ASPM dan/atau mencabut Rekomendasi ASPM;

7) Menerbitkan Pernyataan Kesesuaian Syariah atau Keselarasan Syariah bagi produk dan ketentuan yang diterbitkan oleh Otoritas terkait;

8) Menerbitkan Pernyataan Kesesuaian Syariah atas sistem, kegiatan, produk, dan jasa di LKS, LBS, dan LPS lainnya;

9) Menerbitkan Sertifikat Kesesuaian Syariah bagi LBS dan LPS lainnya yang memerlukan;

10)Menyelenggarakan Program Sertifikasi Keahlian Syariah bagi LKS, LBS, dan LPS lainnya;

11)Melakukan sosialisasi dan edukasi dalam rangka meningkatkan literasi keuangan, bisnis, dan ekonomi syariah; dan

12)Menumbuhkembangkan penerapan nilai-nilai syariah dalam kegiatan perekonomian pada umumnya dan keuangan pada khususnya.

Disamping tugas-tugas pokoknya, DSN-MUI memiliki wewenang sebagai berikut:

1) Memberikan peringatan kepada LKS, LBS, dan LPS lainnya untuk menghentikan penyimpangan dari fatwa yang diterbitkan oleh DSN-MUI;

2) Merekomendasikan kepada pihak yang berwenang untuk mengambil tindakan apabila peringatan tidak diindahkan;

3) Membekukan dan/atau membatalkan sertifikat Syariah bagi LKS, LBS, dan LPS lainnya yang melakukan pelanggaran;

4) Menyetujui atau menolak permohonan LKS, LBS, dan LPS lainnya mengenai usul penggantian dan/atau pemberhentian DPS pada lembaga yang bersangkutan;

5) Merekomendasikankepada pihak terkait untuk menumbuhkembangkan usaha bidang keuangan, bisnis, dan ekonomi syariah; 
6) Menjalin kemitraan dan kerjasama dengan berbagai pihak, baik dalam maupun luar negeri untuk menumbuhkembangkan usaha bidang keuangan, bisnis, dan ekonomi syariah.

Perlu digaris bawahi dari paparan tugas dan wewenang yang dijelaskan sebelumnya, DSN-MUI memiliki fungsi otoritas untuk mengeluarkan fatwa serta memastikan implementasi prinsip syari'ah yang ada pada produk, jasa, dan kegiatan bank telah dijalankan dengan benar. Dengan fungsi tersebut DSN-MUI berwenang menyetujui pengangkatan DPS kemudian menetapkan tugas kepada DPS dalam melakukan fungsi pengawasan dengan pedoman fatwa-fatwa DSN-MUI mengenai prosedur kegiatan usaha yang seharusnya dilaksanakan di lapangan.

\section{Industri Wisata Halal}

Definisi industri yakni usaha pelaksanaan proses produksi (Suwardana, 2018). Wisata halal yakni kegiatan wisata dengan tujuan wisata yang menyediakan fasilitas produk, pelayanan, dan pengelolaan pariwisata yang memenuhi unsur syariah. Dengan kata lain, salah satu bentuk wisata berbasis budaya yang mengutamakan nilai dan norma hukum Islam sebagai landasannya (Rozalinda, dkk, 2019). Sehingga pengertian industri wisata halal yaitu kegiatan bisnis untuk mendapat keuntungan secara ekonomi dan diproyeksikan dalam kebijakan pemerintah, untuk meningkatkan pendapatan masyarakat dalam bidang pariwisata yang bernuansa religi dengan fasilitas dan pelayanan yang tidak menyalahi hukum islam dan memenuhi prinsip syariah (Jaelani, 2017).

Meski bernuansa islami, wisata halal bersifat universal yang artinya dapat dinikmati oleh seluruh kalangan wisatawan dan tidak memandang suku, agama, ras dan golongan tertentu. Maka pariwisata halal termasuk kegiatan yang dapat menyediakan extended service of condition (kondisi layanan prima). Wisata halal tidak menghilangkan semua unsur yang terkandung dalam wisata konvensional. Unsur tersebut tetap ada selama tidak bertentangan dengan nilai dan hukum agama islam (Al-Hassan, 2017). Dengan demikian, dukungan dan pengawasan pemerintah serta 
kinerja industri penyedia wisata halal yang optimal sangat penting untuk merealisasikan industri wisata halal yang standar dalam industri ekonomi global.

\section{METODE PENELITIAN}

Metode yang digunakan dalam artikel ini adalah yuridis-normatif, dengan pendekatan historis, pendekatan konseptual, dan pendekatan Undang-Undang (Marzuki, 2017). Data yang diperlukan dalam artikel ini adalah data sekunder baik dengan bentuk bahan hukum primer seperti Undang-Undang, bahan hukum sekunder seperti buku dan jurnal, dan bahan hukum tersier seperti artikel-artikel lain yang berkaitan dengan pembahasan ini. Bahan hukum diperoleh dengan studi kepustakaan. Metode analisis menggunakan yuridis kualitatif, yaitu bahan hukum tidak dianalisis dengan rumus statistik, melainkan dengan pendekatan penafsiran hukum, dan konstruksi hukum dengan cara berfikir deduktif (Wignjosoebroto, 2013). Tulisan ini akan membahas bagaimana peran DPS dalam memenuhi syariah compliance pada industri wisata halal di Indonesia, memaparkan tinjauan kritis mengenai dominasi ekonomi syariah dalam sektor keuangan, serta menjelaskan pentingnya produk fatwa baru dari DSN-MUI yang diiringi pengawasan ketat DPS pada sektor riil.

\section{HASIL DAN PEMBAHASAN}

Justifikasi Dewan Pengawas Syariah (DPS) dan Dewan Syari'ah Nasional Majelis Ulama Indonesia (DSN-MUI) dalam Penegakan Syariah Compliance di Indonesia

Saat ini, DPS memang lebih banyak difokuskan pada Lembaga keuangan. Anggota DPS diharuskan cakap dan profesional dari segi teori dan praktik serta berpengalaman di bidang Fiqih, Mu'amalah termasuk ekonomi dan keuangan Islam kontemporer. Sebab DPS sebagai penentu tingkat kepatuhan (compliance) bagi suatu perusahaan dan bank terhadap prinsip syari'ah. Juga agar perusahaan atau lembaga yang bersangkutan dipercaya oleh masyarakat yang 
ingin mengelola keuangan dan menjalankan ketaatan terhadap aturan Allah sekaligus menghindari hal-hal yang dilarang oleh syariat agama (Absor, dkk, 2013).

Anggota DPS yang ditempatkan di Lembaga keuangan dan Bank Syari'ah harus mendapat persetujuan dari DSN-MUI. Keputusan DSN-MUI No. 03 Tahun 2000 tentang Petunjuk Pelaksanaan Anggota Dewan Pengawas Syariah pada Lembaga Keuangan Syari'ah menentukan jumlah anggota DPS dalam tiap Lembaga keuangan paling sedikit 3 orang anggota yang salah satunya ditetapkan sebagai ketua. Anggota DPS paling banyak berjumlah setengah dari jumlah Direksi. Tugas utamanya sebagai penasehat atau pemberi saran kepada Direksi, Pimpinan Usaha Syari'ah dan Kantor Cabang Syari'ah dalam hal terkait aspek Syari'ah (Pertiwi, 2019). Selain itu ada beberapa peran yang dijalankan oleh DPS, antara lain (Umam, 2015):

1) Mengamati, mengkaji dan menilai implementasi fatwa DSN-MUI pada manajemen operasional Lembaga keuangan dan Bank Syari'ah

2) Memastikan dan mengawasi secara aktif maupun pasif mengenai penerapan fatwa DSN-MUI dalam Lembaga Keuangan maupun Bank Syari'ah

3) Melakukan sosialisasi dan edukasi kepada masyarakat tentang Bank Syari'ah melalui media yang sudah berjalan seperti pengajian, majlis ta'lim dan khutbah Jum'at

4) Memberikan opini dari aspek syari'ah terhadap pelaksanaan operasional Lembaga keuangan secara keseluruhan dalam laporan publikasi Lembaga keuangan

5) Mengkaji produk dan jasa baru yang belum ada fatwa untuk dimintakan fatwa kepada DSN-MUI

6) Menyampaikan laporan hasil pengawasan syari'ah sekurang-kurangnya setiap 6 (enam) bulan kepada Direksi, DSN-MUI dan Bank Indonesia

Maka korelasi antara DPS dan DSN-MUI dalam hal pengawasan ditambah dengan OJK sebagai penerap sanksi, dapat digambarkan dengan skema berikut ini: 


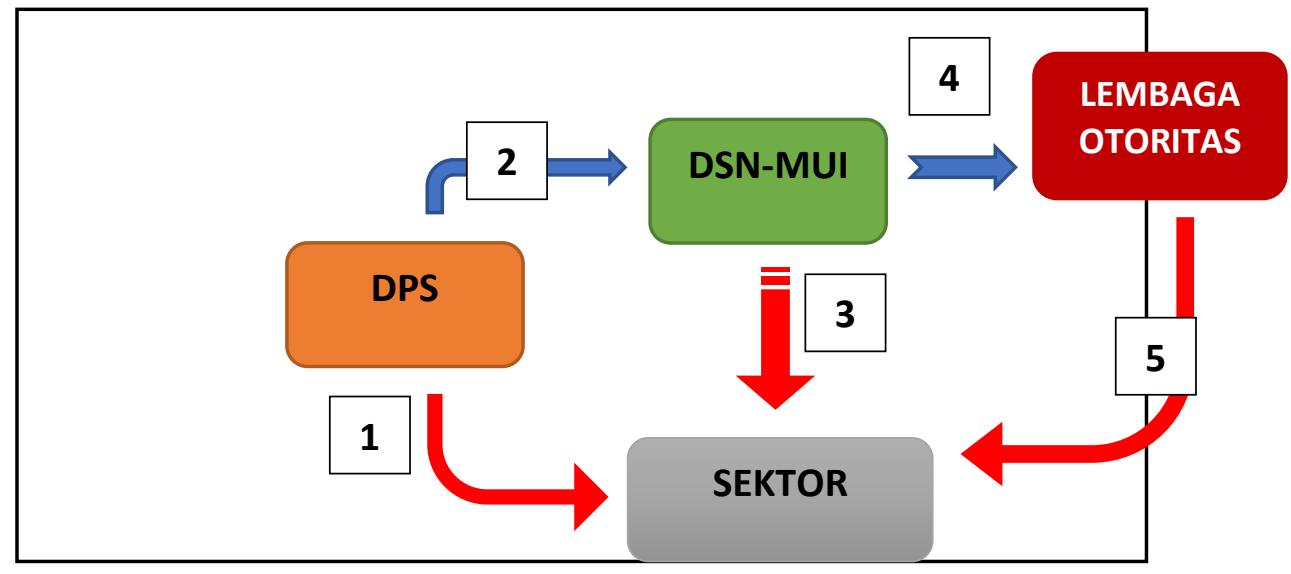

Tabel. Korelasi DPS dan DSN-MUI Sebagai Pengawas Sektor Keuangan

Penjelasan urutan korelasi antara DSN-MUI dan DPS dalam menjalankan fungsi pengawasan dari bagan di atas adalah sebagai berikut:

1) DPS melaporkan segala sesuatu terkait implementasi prinsip dan nilai Syariah yang ada di lapangan termasuk jika terjadi pelanggaran

2) DSN-MUI menerima laporan dari DPS,

3) DSN-MUI mengeluarkan teguran.

4) Apabila teguran tidak diindahkan, selanjutnya DSN-MUI akan mengeluarkan rekomendasi untuk diberikan ke lembaga otoritas terkait. Misalnya pada Perbankan, Pasar Modal, IKNB, maka rekomendasi dikirim ke Otoritas Jasa Keuangan (OJK).

5) Lembaga Otoritas akan menerima rekomendasi dari DSN-MUI, untuk kemudian memberikan tindakan kepada lembaga yang melanggar. Tindakan dapat berupa penerapan sanksi administratif atau hal-hal yang telah ditentukan dalam Undang-Undang.

Apabila dalam kinerja DPS sendiri ditemukan ada sengketa terkait prinsip syari'ah, maka DPS dan/atau siapapun yang berkaitan dengan kesalahan tersebut akan dikenai sanksi administratif sesuai ketentuan pada Undang-Undang Nomor 21 Tahun 2008 tentang Perbankan Syari'ah Pasal 41 dan Pasal 44. Khusus dalam hal asuransi, Undang-Undang Nomor 40 Tahun 2014 telah menentukan kewajiban anggota DPS untuk memenuhi persyaratan kepatuhan dan kepatutan yang mencakup integritas dan kompetensi tugas dan fungsi maupun pengalaman dan keahlian dalam bidang Asuransi Syari'ah. 
Perlu diketahui bahwa aturan mengenai tanggung jawab DPS masih belum terlihat jelas dan tegas seperti ketegasan yang berlaku pada Dewan Komisaris. Tidak ada peraturan yang menjelaskan pertanggungjawaban pribadi DPS terkait kewenangannya dalam penerapan prinsip syari'ah. Padahal peran DPS adalah sebagai kekuatan yang menentukan tingkat compliance suatu Lembaga terhadap prinsip syari'ah dan nilai-nilainya. Apabila tanggung jawab besar ini tidak disertai dengan peraturan dan sanksi yang ketat, maka kemurnian penerapan prinsip syari'ah dari suatu sektor atau lembaga menjadi diragukan. Jika hal ini dibiarkan akan mengakibatkan pada pencemaran kepercayaan masyarakat (Rismayani \& Luthfia, 2018).

Integritas DPS ditegaskan lagi dengan adanya kesimpulan dari penelitian yang dilakukan oleh Arif, bahwa jumlah anggota DPS, Pendidikan DPS, Rangkap Jabatan DPS, Kompetensi DPS, Jumlah Rapat DPS, Reputasi DPS dan Perubahan Komposisi DPS sangat mempengaruhi karakteristik kinerja DPS. Akhirnya karakteristik kinerja DPS yang bermacam-macam itu mempengaruhi kinerja dan resiko pembiayaan di suatu sektor keuangan yang diawasi oleh yang bersangkutan (Nugroho, 2020).

Berdasarkan pemaparan sebelumnya, DPS merupakan Lembaga pengawas di sektor keuangan syariah yang dibentuk oleh DSN-MUI. DSN-MUI dengan produk fatwanya dapat dikatakan sebagai pengawas eksternal Lembaga Keuangan Syariah dan Perbankan Syariah, sedangkan DPS sebagai pengawas internal yang ditempatkan di tiap sektor tersebut menjalankan tugas sesuai pedoman fatwa DSNMUI. Seorang DPS selain sebagai pengawas haruslah cakap dan mampu berlaku sebagai advisor pada sektor keuangan yang ditempati, sebab integritas dan kapabilitas seorang DPS sangat mempengaruhi tindak tanduk lembaga yang diawasinya. Sinergitas antara DPS dan DSN-MUI berpengaruh besar pada penegakan nilai-nilai islam dan hukum ekonomi syariah, karena keduanya menentukan tingkat kepatuhan syariah pada sektor-sektor keuangan di Indonesia. 


\section{Dominasi Ekonomi Syariah dalam Sektor Keuangan: Sebuah Tinjauan Kritis}

Fatwa DSN-MUI sebagai respon baik dari perkembangan ekonomi syariah yang signifikan di Indonesia yang mencakup berbagai sektor. Namun sektor terbesar implementasi ekonomi syariah terletak pada sektor keuangan. Jika awalnya masih terbatas pada sektor perbankan, perluasan setelahnya pun masih seputar keuangan yang meliputi asuransi, pasar modal, dan pembiayaan, selain itu hal ini juga berpengaruh pada sistem hukum di Indonesia (Abdad, 2019).

Proporsionalitas ekonomi syariah di mata masyarakat menempati ruang besar pada sektor keuangan. Apabila diperdengarkan kepada masyarakat tidak menutup kemungkinan yang keluar adalah perbankan syariah, asuransi syariah, obligasi syariah, gadai syariah, dan lain sebagainya. Direktur Pengembangan Ekonomi Syariah dan Industri Halal KNEKS, Afdhal Aliasar, sebagaimana dikutip Azwar Iskandar, dan Khaerul Aqbar, melansir data jumlah pangsa pasar perbankan syariah hanya 5,94 persen, sedangkan pangsa pasar non perbankan syariah hanya 2,75 persen. Perhitungan ini hanya berdasarkan dana masyarakat yang dikelola oleh perbankan syariah (Iskandar \& Aqbar, 2019).

Titik tolak yang terfokus pada sektor keuangan ini hanya sebatas gambaran sempit terkait implementasi ekonomi syariah, hal ini mungkin dapat memberikan pusat perhatian para praktisi ekonomi syariah hanya berkutat pada sektor keuangan, atau finansial semata. Padahal ada banyak sektor lainnya yang mampu diterapkan praktik ekonomi syariah seperti kegiatan perekonomian di pasar tradisional, pertanian, industri, dan bisnis lainnya. Prosentase angka sebelumnya menunjukkan bahwa perkembangan sektor keuangan lebih cepat daripada sektor riil. Padahal jika hal itu terus menerus terjadi bukan tidak mungkin terjadi economic bubble, inflasi dan ketimpangan neraca pembayaran dan capital outflow (Gunawan, 2019).

Prospek kedepannya sektor keuangan akan bergantung pada sektor riil. Sebab sektor keuangan tidak dapat terjun langsung ke dalam sektor riil 
yang dapat menghasilkan laba halal. Dalam sektor finansial, uang menjadi penggerak ekonomi, bukan objek perekonomian. Objek perekonomian terletak pada barang, atau jasa, yang dinilai dengan uang. Selanjutnya apabila uang yang pada dasarnya sebagai alat transaksi, dan niaga dijadikan sebagai objek utama perekonomian, maka jatuhnya adalah riba sehingga muncul banyak spekulasi, dan kekacauan. Meskipun begitu, kedua sektor ini saling bersinergi, namun untuk memenuhi ketaatan dalam penerapan ekonomi syariah tentunya saling bergerak dengan pola syariah pula [28]. Dengan demikian peran sektor keuangan khususnya perbankan dan lembaga keuangan syariah dapat memainkan peran paling penting untuk mendorong roda perekonomian negara. Karena sistem bagi hasil yang merupakan brand image sektor tersebut berpeluang besar meningkatan investasi pada sektor riil (Iswanto, 2020).

Sudah saatnya sektor selain keuangan patut diperhatikan untuk meningkatkan perkembangan ekonomi syariah. Jika pada dasarnya dana pihak ketiga telah banyak diperuntukan untuk sektor keuangan, maka keuntungan diperoleh dari penyaluran dana semata, bukan dari perniagaan secara riil, sehingga bisa dikhawatirkan apabila aliran dana pihak ketiga mengalir banyak namun sektor riil tidak mampu menampung. Untuk itu, para praktisi ekonomi syariah hendaknya memusatkan kembali pada sektor riil, perniagaan praktis, dan sektor industri, untuk mendapatkan keuntungan dari perniagaan riil, bukan hanya dari praktik sektor keuangan yang hanya mempertukarkan uang semata. Sehingga dominasi yang terjadi pada perkembangan sektor keuangan akan segera diimbangi dengan perkembangan dalam sektor riil, dan salah satu yang berperan penting dalam perekonomian nasional dan internasional adalah industri wisata halal.

\section{Keterlibatan DSN-MUI dan DPS Dalam Pengembangan Industri Wisata Halal}

Penting diketahui sesungguhnya tanggungan DPS tidak hanya pada sektor keuangan saja, sebab geliat pertumbuhan ekonomi syari'ah juga merambah pada sektor riil, yaitu sektor yang berkaitan secara langsung 
pada kegiatan ekonomi di masyarakat. Keberadaan sektor riil menjadi salah satu kriteria yang mampu menjadi mesin penggerak roda perekonomian sehingga mempengaruhi pertumbuhan ekonomi di suatu negara (Beik \& Arsyianti, 2016). Sektor-sektor itu meliputi kegiatan produksi perusahaan, produksi rumah tangga serta lembaga-lembaga penghasil barang-barang yang dapat dikonsumsi langsung maupun diambil manfaatnya untuk diproduksi lebih banyak lagi. Sektor pertanian, sektor pertambangan, sektor industri pengolahan, sektor gas, sektor listrik, dan sektor air bersih juga termasuk dalam kategori sektor riil karena berada diluar sektor keuangan.

Beberapa sektor itulah yang justru menjadi tempat bagi masyarakat untuk bekerja dan mendapat penghasilan nyata. Kapasitas sektor riil yang tinggi akan mengurangi tingkat pengangguran, meninggikan pendapatan dan dampaknya mendorong pertumbuhan ekonomi. Menjadi semakin jelas bahwa tingkat konsumsi, pekerjaan dan pendapatan seseorang dijadikan tolok ukur kesejahteraan dalam dinamika masyarakat. Ketiga faktor tersebut berasal dari sektor riil yang mestinya bisa dijadikan peluang agar ekonomi syari'ah di Indonesia dapat tumbuh lebih optimal. Dengan demikian urgensi pengawasan khusus pada sektor riil harus segera dioptimalkan untuk menjamin implementasi prinsip syariah benar-benar berjalan sesuai hukum islam serta tidak disalahgunakan hanya untuk menjual label syari'ah saja.

Sangat disayangkan karena DPS tidak dapat bergerak masif sebagai pengawas tanpa pedoman fatwa-fatwa DSN-MUI. Mengingat DPS adalah perpanjangan tangan dari DSN-MUI dalam mengontrol implementasi prinsip syariah pada sektor-sektor tersebut, maka yang mesti didahulukan adalah berlakunya fatwa-fatwa dari DSN-MUI yang mengatur seluruh dimensi aktivitas ekonomi dalam sektor terkait, yang dalam hal ini adalah sektor riil perekonomian syariah.

Problem yang terjadi saat ini bahwa diantara fatwa-fatwa DSN-MUI yang berlaku dari nomor 01 hingga nomor 137 fatwa itu sebagian besar mengatur pada sektor keuangan seperti perbankan dan lembaga 
keuangan non-bank. Hanya ada beberapa sektor riil yang telah memiliki pedoman fatwa DSN-MUI secara spefisik diantaranya; Fatwa nomor 83/DSN-MUI/VI/2012 tentang Penjualan Langsung Berjenjang Syariah Jasa Perjalanan Umrah, Fatwa nomor 98/DSN-MUI/XII/2015 tentang Pedoman Penyelenggaraan Jaminan Sosial Kesehatan Syariah, Fatwa nomor 107/DSN-MUI/X/2016 tentang Pedoman Penyelenggaraan Rumah Sakit Berdasarkan Prinsip Syariah, dan Fatwa nomor 108/DSN$\mathrm{MUI} / \mathrm{X} / 2016$ tentang Pedoman Penyelenggaraan Pariwisata Berdasarkan Prinsip Syariah (Fatwa DSN MUI).

Salah satu contoh dari sektor riil yang memberlakukan konsep syariah adalah dari perhotelan syariah yang memberikan kontribusi cukup baik bagi industry pariwisata Indonesia. Beberapa kota seperti Jakarta, Bandung, Medan, Kendari, Surabaya, Semarang dan Yogyakarta memiliki hotel syariah kelas bintang dan non-bintang yang telah berkembang dengan baik. Namun, perlu dievaluasi pula bahwa hotel syari'ah memang tidak banyak berbeda dengan hotel-hotel pada umumnya, penekanannya pada penyediaan berbagai fasilitas dan pelayanan yang tunduk pada nilainilai aturan Islam. Tapi pada faktanya implementasi syari'ah masih belum mencakup keseluruhan. Dilihat dari orientasi pasar, hotel syari'ah cenderung menerapkan pelayanan kepada wisatawan muslim padahal poin pentingnya adalah kemampuan untuk mengkondisikan keberagaman wisatawan yang menginap di hotel tersebut.

Misalnya pada fasilitas dalam kamar hotel yang menyediakan AlQur'an dan sajadah untuk kemudahan sarana ibadah yang tidak dapat dimanfaatkan oleh wisatawan non-muslim. Kemudian pada desain interior berupa pajangan ka'bah ataupun kaligrafi serta simbol islami lainnya. Satu hal yang pasti dapat dirasakan oleh wisatawan muslim maupun nonmuslim yakni adanya aturan pemisahan tamu laki-laki dan perempuan yang bukan mahrom atau belum menikah. Hotel syari'ah berusaha untuk membangun citra positif dan menghapus kesan negatif yang sering timbul pada masyarakat jika memandang industri perhotelan maupun tempat penginapan lainnya. Aturan pemisahan tersebut diinformasikan kepada 
para tamu secara terbuka melalui lisan dan/atau tulisan ketika seseorang akan melakukan proses reservasi dan check-in.

Lebih lanjut dengan berlakunya Fatwa Nomor 108/DSN-MUI/X/2016 tentang Pedoman Penyelenggaraan Pariwisata Berdasarkan Prinsip Syariah merupakan produk DSN-MUI yang menjadi salah satu pedoman DPS dalam menjalankan fungsi pengawasan sekaligus panduan bagi penyedia jasa industri pariwisata. Di dalam Fatwa Nomor 108/DSNMUI/X/2016 tentang Pedoman Penyelenggaraan Pariwisata Berdasarkan Prinsip Syariah dijelaskan terkait ketentuan umum, ketentuan hukum, prinsip umum penyelenggaraan wisata, ketentuan para pihak dan akadnya, ketentuan hotel syariah, ketentuan wisatawan, ketentuan destinasi wisata, ketentuan layanan spa dan sejenisnya, ketentuan biro perjalanan wisata, ketentuan pemandu wisata, dan ketentuan penutup (DSN-MUI, 2016).

Fatwa yang dikeluarkan tahun 2016 tersebut berfungsi sebagai standar implementasi prinsip syariah bagi industri perhotelan syariah di Indonesia. Analisis menggunakan Fatwa Nomor 108/DSN-MUI/X/2016 telah dilakukan terhadap beberapa bisnis perhotelan dan industri wisata di Indonesia antara lain;

1) Penelitian Khusnul Nur Aisyah yang menyimpulkan bahwa fasilitasi dan akomodasi perhotelan di Ponorogo, tepatnya di hotel Sankita Syariah dan Hotel Latibantelah berjalan sesuai fatwa dengan adanya tata tertib tamu yang tidak menerima pasangan yang bukan mahromnya, busana pegawai sesuai prinsip Syariah, hotel tidak memperlihatkan dekorasi/ornamen patung dan lukisan yang mengandung unsur pornografi, hanya saja penyediaan konsumsi bagi tamu belum memenuhi syarat sebab belum bersertifikat halal dari MUI (Khusnul, 2018).

2) Penelitian Dewi Masdaleny yang dilakukan di G Hotel Syariah Bandar Lampung menyimpulkan bahwa pelayanan tamu yang tersedia dilakukan sangat cepat dan baik, tidak membedakan ras dan golongan, pengelolaan, produk dan pelayanan secara umum telah sesuai dengan fatwa terkait. Namun masih terdapat beberapa hal yang belum dipenuhi seperti; pengadaan sertifikasi makanan dan/atau minuman halal dari MUI serta penyediaan jasa perbankan syariah dalam pelayanan transaksi keuangan. 
3) Penelitian oleh Emi Rahmawati yang dilakukan di Hotel Multazam Syariah menjelaskan bahwa hotel tersebut masih beradaptasi dengan adanya fatwa tersebut dan belum mendapatkan sertifikasi dari MUI. DPS belum masuk dalam struktur organisasi sebagai pengawas syariah compliance, makanan dan minuman hotel belum mendapat sertifikasi halal MUI, dan pelayanan hotel belum memiliki SOP yang dipublikasikan bagi tamu hotel. Hotel juga tidak menyediakan layanan pub, bar, kolam renang dan berbagai fasilitas yang dapat mengakibatkan ketidaksesuaian dengan prinsip-prinsip syariah. Namun secara umum hotel itu telah memenuhi ketentuan-ketentuan dalam Fatwa DSN-MUI Nomor: 108/DSN-MUI/X/2016.

4) Penelitian di Hotel Rumah Kayu Syariah Lembang oleh Alfi Khairuni Ramdhan, Asep Ramdan Hidayat, dan Eva Misfah Bayuni menarik kesimpulan bahwa pelayanan, produk dan pengelolaan Hotel Rumah Kayu Syariah berdasarkan uji persepsi konsumen hanya meraih 2 dari 7 kriteria yang ditetapkan Fatwa DSN-MUI serta persepsi konsumen hanya $5 \%$ dari jumlah pengunjung pada dua tahun terakhir yang beranggapan Hotel tersebut sesuai prinsip syariah. Artinya 95\% responden sisanya belum beranggapan hotel tersebut sesuai prinsip dan nilai syariah sebagaimana ditentukan dalam Fatwa DSN-MUI No. 108/DSN-MUI/X/2016 (Ramdhan, dkk, 2019).

5) Penelitian pada Tours dan Travel PT. Daanish Mika Salsa Kecamatan Sukarame Bandar Lampung yang dilakukan oleh Ervina Clara Agustin memaparkan hasil bahwa pelaksanaan pariwisata syariah belum sepenuhnya memenuhi standar yang ditentukan pada Fatwa DSN-MUI No. 108/DSN$\mathrm{MUI} / \mathrm{X} / 2016$ karena belum menyediakan proses administrasi pembayaran via transfer bank syariah. Namun PT. Daanish Mika Salsa Kecamatan Sukarame Bandar Lampung sudah memiliki sertifikasi makanan dan minuman halal dari MUI, penyediaan akomodasi dan destinasi wisata sudah memenuhi ketentuan dalam fatwa tersebut, serta penjelasan mengenai pelayanan pariwisata dan fasilitas yang diberikan pada pelanggan menunjukkan kesesuaian ternadap prinsip syariah (Agustin, 2018).

Paparan data tersebut menguatkan urgensi pengawasan dan pengawalan DPS pada lapangan sektor riil. Hal itu ditunjukkan dengan adanya beberapa hotel berlabel syariah masih beradaptasi dan belum menyempurnakan kesesuaian prinsip Syariah yang ditentukan pada Fatwa DSN-MUI No. 108/DSN-MUI/X/2016. Terlebih Fatwa Tentang 
mengarah kepada industri perhotelan saja sedangkan hotel hanya salah satu dari sekian sarana dalam bidang kepariwisatan dan bukan satusatunya destinasi pariwisata (Dewi, 2020).

Kurangnya pengawasan DPS pada industri pariwisata di atas menunjukkan produk Fatwa DSN-MUI masih terkesan sempit dan belum mencakup seluruh aspek untuk menjadi pedoman implementasi prinsip syariah pada berbagai industri sektor riil, sehingga membatasi kinerja DPS dalam pengawasan sektor riil untuk mengimplementasikan nilai-nilai dan prinsip syariah secara keseluruhan. Jika hal ini tidak segera ditindaklanjuti oleh pihak yang memiliki kewenangan, bukan hal mustahil akan bemunculan sektor riil industri pengadaan barang dan jasa lainnya di Indonesia yang hanya berlabel syariah namun tidak memenuhi prinsip dan nilai-nilai hukum ekonomi syariah. Akibatnya mencemari kepercayaan masyarakat, terutama mayoritas umat muslim, dalam kancah nasional dan internasional mengenai perekonomian syariah di Indonesia.

\section{KESIMPULAN}

Pentingnya peran DSN-MUI sebagai pengawas eksternal dan DPS sebagai pengawas internal berpengaruh besar pada kepatuhan prinsip syariah di sektor keuangan. Hal yang perlu dievaluasi dari perkembangan ekonomi syariah di Indonesia yaitu bahwa fatwa-fatwa dari DSN-MUI serta pengawasan dari DPS masih berkutat pada sektor keuangan saja, sehinga pengaruh yang diberikan oleh regulasi dan regulatornya pada sektor keuangan dan sektor riil belum seimbang. Akan tetapi, jika fokus sekarang ini masih pada sektor keuangan hal ini juga penting sebagai roda penggerak sektor riil lainnya yang memang harus bersinergi dengan pola syariah agar tercipta siklus perekonomian syariah secara penuh, baik secara sektor keuangan sebagai alat, dan sektor riil lain sebagai objek perekonomian.

Perlu dipahami bahwa sektor keuangan bukan hanya sekedar alat untuk memperoleh keuntungan dengan mempertukarkan uang dengan uang yang nantinya jatuh sebagai riba, namun perlu keseimbangan dengan sektor perdagangan riil lainnya untuk mewujudkan perekonomian 
berbasis syariah. Maka peran DSN-MUI dalam mengeluarkan Fatwa produk syariah baru harus segera dilakukan dan pengawasan DPS pada sektor riil mestinya diperketat karena sektor riil telah berkembang sangat pesat namun masih ditemukan ketidakpatuhan pada prinsip-prinsip syariah.

\section{DAFTAR PUSTAKA}

A. F. Ulumi, 2020, IMPLEMENTASI HUKUM EKONOMI SYARI'AH PADA LEMBAGA KEUANGAN SYARIAH, TAHKIM, Vol. 15, No. 2, pp. 235-254.

A. Mujib, 2016, Analisis Terhadap Konsep Syariah Pada Industri Perhotelan Di Indonesia, Asy-Syir'ah J. Ilmu Syari'ah dan Huk., Vol. 50, No. 2, pp. 425-447.

A. K. Munthe, I. S. Praramadhani, and R. I. Satrya, 2019, Peran Dewan Pengawas Syariah Dalam Pemenuhan Shariah Compliance Oleh Lembaga Keuangan Syariah, Sharia J. Islam. Law Stud., Vol. 2, No. 3 , [Online]. Available: http://js.law.ui.ac.id/index.php/about/article/view/46/pdf.

B. Iswanto, 2016, Peran Bank Indonesia, Dewan Syariah Nasional, Badan Wakaf Indonesia Dan Baznas Dalam Pengembangan Produk Hukum Ekonomi Islam Di Indonesia, lqtishadia J. Kaji. Ekon. dan Bisnis Islam Stain Kudus, Vol. 9, No. 2, pp. 421-439.

A. R. M. Wahyu and W. A. Anwar, 2020, Dewan Pengawasan Syariah Pada Bank Syariah (Tinjauan Undang-Undang Perbankan Syariah), Al-Azhar J. Islam. Econ., Vol. 2, No. 2, pp. 82-93, doi: 10.37146/ajie.v2i2.44.

E. M. I. RAHMAWATI, , ANALISIS FATWA DSN-MUI NOMOR: 108/DSNMUI/X/2016 TENTANG PEDOMAN PENYELENGGARAAN PARIWISATA BERDASARKAN.

E. A. Hardi, 2019, Fatwa DSN MUI Dan Perkembangan Produk Perbankan Syariah Di Indonesia, An-Nisbah J. Ekon. Syariah, Vol. 6, No. 1, pp. 82-105.

T. Risal, 2019, Peningkatan Peran Perbankan Syariah Dengan Menggerakkan Sektor Riil Dalam Pembangunan, Accumulated, Vol. 1, No. 1, pp. 36-47, [Online]. Available: http://e-journal.potensiutama.ac.id/ojs/index.php/Accumulated/article/view/581/794.

R. Mahardika, 2020, Strategi Pemasaran Wisata Halal, Mutawasith J. Huk. Islam, Vol. 3, No. 1, pp. 65-86.

R. B. Faizal Irany Sidharta, 2018, Optimalisasi Peran Perbankan Syariah Dalam Mendukung Wisata Halal, Distrib. - J. Manag. Bus., Vol. 5, No. 2, pp. 1-14, doi: 10.29303/jdm.v5i2.29.

H. Syaifullah, 2019, Penerapan Fatwa DSN-MUI Tentang Murabahah Di Bank Syariah, Kordinat| J. Komun. Antar Perguru. Tinggi Agama Islam, Vol. 17, No. 2, pp. 257-282. 
M. Dewi, 2020, PRAKTEK PENGEMBANGAN PARIWISATA SYARIAH DALAM PERSPEKTIF FATWA DSN-MUI NO. 108/DSN-MUI/X/2016. UIN Raden Intan Lampung.

M. Baaqy, 1987, محمد فؤاد عبد الباقي، المجم الدفوس لأحفظ القرآن - Penelusuran Google. Daar al-Hadits, 1987.

I. Taimiyyah, , الحسبة في الإسلام أو وظيفة الحكومة الإسلامية - ابن تيمية - Google Buku. Beirut: Daar al-Kutub al-Islamiyah.

[Sekilas - DSN-MUI. https://dsnmui.or.id/kami/sekilas/ (accessed Mar. 04, 2021).

H. Suwardana, 2018, Revolusi Industri 4. 0 Berbasis Revolusi Mental, JATI UNIK J. IIm. Tek. Dan Manaj. Ind., Vol. 1, No. 2, pp. 109-118.

R. Rozalinda, N. Nurhasnah, and S. Ramadhan, 2019, Industri Wisata Halal Di Sumatera Barat: Potensi, Peluang Dan Tantangan, Maqdis J. Kaji. Ekon. Islam, Vol. 4, No. 1, pp. 45-56.

A. Jaelani, 2017, Halal Tourism Industry In Indonesia: Potential And Prospects, Int. Rev. Manag. Mark., Vol. 7, No. 3.

F. A. Al Hasan, 2017, Penyelenggaraan Parawisata Halal Di Indonesia (Analisis Fatwa DSN-MUI Tentang Pedoman Penyelenggaraan Pariwisata Berdasarkan Prinsip Syariah) [Organizing Halal Tourism In Indonesia (Analysis Of DSN-MUI Fatwa On Guidelines For Organizing Tourism Based On S, al-Ahkam, Vol. 2, No. 1, pp. 59-77, [Online].

Available: https://www.researchgate.net/publication/323960421.

P. Marzuki, 2017, Penelitian Hukum: Edisi Revisi - Prof. Dr. Mahmud Marzuki - Google Buku. Jakarta: PT Kharisma Putra Utama, 2017.

S. Wignjosoebroto, 2013, Hukum: Konsep dan Metode. Malang: Setara Press, 2013.

C. Absor, K. F. Hana, and F. R. Nur, 2019, Ada Apa Dengan Dewan Pengawas Syariah Di Koperasi Simpan Pinjam Dan Pembiayaan Syariah?, MALIA J. Islam. Bank. Financ., Vol. 3, No. 2, p. 155, doi: 10.21043/malia.v3i2.8413.

D. Pertiwi, 2019, Peran Dewan Pengawas Syariah (DPS) Dalam Mewujudkan Good Corporate Governance Di Bank Syariah, J. BAABU AL-ILMI Ekon. dan Perbank. Syariah, Vol. 4, No. 1, pp. 1-18.

K. Umam, 2015, Urgensi Standarisasi Dewan Pengawas Syariah Dalam Meningkatkan Kualitas Audit Kepatuhan Syariah, J. Perhimpun. Mhs. Huk. Indones. Cab. Drh. Istimewa Yogyakarta, Vol. 1, No. 2, pp. 114-138.

G. Rismayani and U. N. Luthfia, 2018, Pengaruh Dewan ... (Gista, Ulfa), J. Ris. Akunt. dan Keuang., Vol. 4, No. 2, pp. 40-53.

A. Nugroho, 2020, Studi Efektivitas Dewan Pengawas Syariah Terhadap Profitabilitas Dan Resiko Pembiayaan Perbankan Syariah, Proceeding Natl. Conf. Account. Financ., Vol. 2, No. 2010, pp. 6068, doi: 10.20885 /ncaf.vol2.art6.

M. Z. Abdad, 2019, SIGNIFIKANSI FATWA DSN MUI TERHADAP PERKEMBANGAN EKONOMI SYARIAH DI INDONESIA, istinbath, Vol. 18, No. 2. 
A. Iskandar and K. Aqbar, 2019, Reposisi Praktik Ekonomi Islam: Studi Kritis Praktik Ekonomi Islam Di Indonesia, NUKHBATUL'ULUM J. Bid. Kaji. Islam, Vol. 5, No. 1, pp. 39-53.

F. B. Gunawan, 2019, Hubungan Kausalitas Antara Sektor Keuangan Dan Sektor Riil Di Indonesia, J. Akunt., Vol. 11, No. 1, pp. 44-60.

B. Iswanto, 2020, TANTANGAN EKONOMI SYARIAH ZAMAN MODERN, J. Stud. Islam Lintas Negara (Journal Cross Bord. Islam. Stud., Vol. 2, No. 1, pp. 16-29.

I. S. Beik and L. D. Arsyianti, 2016, Ekonomi Pembangunan Syariah. Jakarta: Rajawali Pers, PT Rajagrafindo Persada (Divisi Buku Perguruan Tinggi), 2016.

Fatwa - DSN-MUI. https://dsnmui.or.id/kategori/fatwa/ (accessed Mar. 04, 2021).

DSN-MUI, 2016, 108 - Fatwa Pariwisata Syariah.pdf - Google Drive. Indonesia, 2016.

N. A. Khusnul, 2018, Analisis Fatwa Dewan Syariah Nasional Mui Tentang Pedoman Penyelenggaraan Pariwisata Berbasis Syariah Terhadap Usaha Perhotelan Di Ponorogo. IAIN PONOROGO.

A. K. Ramdhan, A. R. Hidayat, and E. M. Bayuni, 2019, Tinjauan Fatwa DSN-MUI No. 108/DSN-MUI/X/2016 Tentang Pedoman Penyelenggaraan Pariwisata Berdasarkan Prinsip Syariah Dan Persepsi Konsumen Tentang Hotel Syariah Kawasan Wisata Di Lembang (Studi Kasus Hotel Rumah Kayu Syariah).

E. C. Agustin, 2018, Implementasi Fatwa DSN-MUI No. 108/DSNMUI/X/2016 Tentang Pedoman Penyelenggaraan Pariwisata Berdasarkan Prinsip Syariah (Studi Pada Tours Dan Travel PT. Daanish Mika Salsa Kecamatan Sukarame Bandar Lampung), Universitas Islam Negeri Raden Intan Lampung, 2018. 